\title{
Differences in English Proficiency Test Scores between Students of Social and Natural Sciences
}

\author{
Usman Kasim
}

Syiah Kuala University, Indonesia, usman@unsyiah.ac.id

\section{Asnawi Muslem}

Syiah Kuala University, Indonesia, drasnawi@unsyiah.ac.id

\section{Faisal Mustafa}

Corresponding author, Syiah Kuala University, Indonesia, faisal.mustafa@ unsyiah.ac.id

Students of social and natural sciences are expected to achieve different learning outcomes because they employ different language learning strategies and are exposed to different vocabulary. This research was aimed at finding evidence from empirical data to determine whether the differences in learning outcomes are statistically significant. The data for this research were collected by administering the Test of English as a Foreign Language (TOEFL) to 179 students from four state universities in Aceh, the northernmost province of Indonesia. The results of the test were analysed based on the components in each subtest. There are three parts in the listening comprehension section, 14 aspects in the structure and written expression section, and six skills in the reading comprehension section. The results show that significant differences were only found in part A (the short talk section) of the listening comprehension part and in the main idea skill section in the reading comprehension part. Students of natural sciences performed better when listening to a short academic talk, while social science students had a better general comprehension of non-discipline specific academic texts.

Keywords: English proficiency, social sciences, natural sciences, Test of English as a Foreign Language, English teaching

\section{INTRODUCTION}

When language teaching and learning was started, language instructors only had limited options for teaching methods. Previously, methods focused on teaching structural skills, but at the end of the twentieth century the direction of language teaching changed with the emergence of communicative language teaching, motivated by research studies.

Citation: Kasim, U., Muslem, A., \& Mustafa, F. (2019). Differences in English Proficiency Test Scores between Students of Social and Natural Sciences. International Journal of Instruction, 12(1), 479-492. https://doi.org/10.29333/iji.2019.12131a 
Development in language teaching and learning research has innovated the way language teachers deliver language instruction. One major area of development covers differentiating teaching methods between individual students based on their learning styles, learning strategies, affective variables, age, sex, motivations, and personalities (Ehrman, Leaver, \& Oxford, 2003, p. 313; Zafar \& Meenakshi, 2012, p. 639), although one study has found that teaching methods do not have a significant effect on students' learning achievement (Muslem \& Abbas, 2017). Another factor that can influence differences in learning outcome is educational discipline. Khurshid and Mahmood (2012, p. 677) found that learning styles vary between students in different disciplines. In addition, differences were also found in academic confidence (Shaukat \& Bashir, 2015), level of anxiety (Putri, Lubis, \& Sutaryan, 2014), and learning strategies (Peacock \& Ho, 2003). As these variables have been found to affect learning, it follows that students of social and natural sciences should receive language instruction differently.

There have been several research studies which address these differences. However, most studies have only investigated whether the differences are significant (Peacock \& Ho, 2003). The results of this research revealed that there are significant differences in language learning strategies and learning style across different disciplines (Litzinger, Lee, Wise, \& Felder, 2005; Sahragard, Khajavi, \& Abbasian, 2016, p. 10; Wang, 2007, pp. 414-415). There are, however, very few research studies which focus on the differences in individual language components, such as listening, structure, and reading. The current study analysed the results of a standardized English proficiency test to find out whether students of social and natural sciences performed differently in each aspect of listening, structure, and reading. The results of this research are expected to help better direct the foci of teaching and learning processes when a teacher teaches students from different disciplines.

\section{History of English as a Foreign Language Teaching}

Language teaching in Europe dates back to the middle of the eighteenth century, when there was a need to study classical languages (Howatt \& Smith, 2014, p. 78). The Grammar Translation Method and the Classical Method dominated the language teaching in that century (Hilgendorf, 2012, p. 2522). A century later, English language teaching began, and the main concern in language teaching shifted to a "scientific basis for teaching." Fifty years later, English language teaching for real-life communication was introduced (Howatt \& Smith, 2014, p. 78).

Unlike Spanish, which has been taught as a foreign language since around the late fifteenth century (Sánchez, 2014, p. 59), or French, which has been taught since the middle of fourteenth century, the teaching of English as a foreign language (TEFL) did not start until the end of the nineteenth century (Howatt, 1984, p. 13). It began in London, where teachers taught English to immigrants. Later, at the end of the eighteenth century, the teaching of English spread outside Europe and North America (Howatt, 1984, p. 300). In Asia, such as in Japan, Indonesia, Thailand, and Malaysia, English was learned as a foreign language starting in the nineteenth century (Darasawang, 2007; Gaudart, 1987; Løfsgaard, 2015; Tsuchiya, 1975). 


\section{Learners' characteristics in TEFL}

The development of research in language teaching has enabled EFL teachers to design different materials and deliver different methods and techniques of teaching based on learners' characteristics. This categorization was well-established after the birth of variationist research in second language acquisition in the third quarter of the 1990s (Regan, 2013, p. 276). Herschensohn and Young-Schholten (2013, p. 2) divide the differences into two main categories, i.e. internal and external characteristic differences. The internal factors that influence second language acquisition include the role of L1(Foley \& Flynn, 2013), the role of working memory (Towell, 2013), poverty of stimulus (Schwartz \& Sprouse, 2013), the learner's psychological factors (Dewaele, 2013), and alphabetic literacy (Tarone, Hansen, \& Bigelow, 2013). On the other hand, the external factors include language exposure (Mayo \& Soler, 2013), language identity construction (Miller \& Kubota, 2013), socialization (Véronique, 2013), variation (Regan, 2013), electronic interaction, and resource (Ensslin \& Krummes, 2013).

\section{EFL Learners across Social and Natural Science Disciplines}

One of the characteristics that contributes to differences in language learning outcomes is academic discipline. Academic discipline is related to language exposure (Schmitt, 2000, p. 116) and learning strategies (Peacock \& Ho, 2003; Sahragard et al., 2016). Language exposure leads to differences in vocabulary learning. Some studies have revealed that students' vocabulary knowledge is different across disciplines (Durrant, 2016, pp. 53-54; Simpson-Vlach, 2012). This difference affects students' reading comprehension because, as Nation and Waring (1997, p. 16) found, vocabulary usage is different across different disciplines. In addition, the language learning strategy used is another factor differentiating language learning across disciplines. Students from social science disciplines tend to use cognitive, metacognitive, compensatory and social strategies, while those from natural sciences have a higher tendency to use affective strategies (Peacock \& Ho, 2003, p. 186). Other research studies also found that social strategies are popular among natural science students (Harish, 2014, p. 70). The conflicting results in previous studies are subject to other variables, such as English proficiency of the research subjects. There is a consensus that advanced learners employ more strategies than their lower level counterparts (Hashemi \& Hadavi, 2015, p. 634; O'Malley \& Chamot, 1990, p. 127; Salahshour, Sharifi, \& Salahshour, 2013, p. 640). The preferred strategies of advanced learners, as reported by Luo and Weil (2014, p. 107), are memory, cognitive, compensation, and affective strategies.

\section{English Proficiency Test}

Success in language learning can be measured through a language test. TOEFL (Test of English as a Foreign Language), IELTS (International English Language Testing System), TOEIC (Test of English for International Communication), and PTE (Pearson Test of English) are English language tests accepted as standardized tests. The tests are accepted by institutions that need proof of English proficiency (Brown, 2004, p. 84). Among those tests, the paper-based TOEFL test has been claimed to be the most popular English standardized test because it is easy to obtain and even to make independently (Mustafa, 2015; Mustafa \& Apriadi, 2016). The test consists of three 
sections, i.e. listening comprehension (50 items), structure and written expression (40 items), and reading comprehension (50 items). The listening comprehension section tests the ability to understand short, extended academic subject-related conversation and short talk. The structure and written expression section measures the ability to recognize correct English grammar. Finally, the reading comprehension section tests the ability to find main ideas, detailed information, references, inferences, and synonyms. Because of its high reliability level, the paper-based TOEFL has been extensively used as a research instrument (Alavi \& Akbarian, 2012; Griffiths \& Oxford, 2014; Hong-Nam \& Leavell, 2006). In addition, the test has also been used as the subject of research, such as research to determine how EFL learners performed while taking the test. Putra, Kasim, and Mustafa (2017) found that vocabulary and inferences are the most difficult aspects of the reading comprehension section. In the structure and written expression section, Ananda (2016) revealed that the most difficult aspects are inversions, verbs, adverb clauses, reduced adjective clauses, and parts of speech. Finally, both the long conversation and short talk sections are the most difficult for EFL students (Abdul \& Abboud, 2011, p. 126).

One of the gaps in the current literature on the differences between students of social and natural sciences is the scientific evidence on whether the results of language learning are different. Therefore, this research provided the evidence by answering the following research questions:

1. Is there any significant difference in the English proficiency test scores between students of social and natural sciences in listening comprehension?

2. Is there any significant difference in the English proficiency test scores between students of social and natural sciences in structure?

3. Is there any significant difference in the English proficiency test scores between students of social and natural sciences in reading comprehension?

\section{METHOD}

\section{Research design}

The study used a quantitative research design, meaning that the data were collected by using a proficiency test. The research was begun by selecting English proficiency test material as the instrument of the research. Afterwards, the writers used the selected English proficiency test to assess participants' English proficiency level to be compared with their academic discipline, either social or natural sciences. Primary data in the form numbers were used and analysed by using statistical procedure, as outlined by Doryei (2007, pp. 32-33).

\section{Participants}

This quantitative study was conducted by involving 179 college students from four state universities in Aceh, Indonesia. They were selected by using a convenience sampling technique, the selection of sample which is based on the ease of access (Kothari, 2004, p. 15). In this research, the students who responded to the invitation were taken as the samples. The distribution between students of social sciences and those of natural sciences was effectively equal, with only a slight difference, i.e. 89 social science students and 90 natural science counterparts. 


\section{Data Collection Tool}

The instrument used in this research was a PBT TOEFL test provided by the Educational Testing Service (ETS). The test consists of three sections, i.e. listening comprehension, structure and written expression, and reading comprehension in multiple choice form. The listening comprehension section includes a short dialogue, a long dialogue, and a long talk. The structure and written expression section covers 14 grammatical aspects, and the reading comprehension section tests six reading skills. The details are presented in Table 1and Table 2.

Table 1

Details of structure and written expression test

\begin{tabular}{lll}
\hline No & Grammatical Aspects & $\begin{array}{l}\text { No. of } \\
\text { questions }\end{array}$ \\
\hline 1 & Adjective Clause & 4 \\
2 & Adverb Clause & 2 \\
3 & Article & 2 \\
4 & Comparison & 2 \\
5 & Conjunction & 3 \\
6 & Inversion & 2 \\
7 & Noun & 3 \\
\hline
\end{tabular}

\begin{tabular}{lll}
\hline No & Grammatical Aspects & $\begin{array}{l}\text { No of } \\
\text { questions }\end{array}$ \\
\hline 8 & Pronoun & 2 \\
9 & Reduced Adjective Clause & 2 \\
10 & Reduced Adverb Clause & 2 \\
11 & Subject and Verb & 4 \\
12 & Verb form & 5 \\
13 & Word Form & 5 \\
14 & Word Order & 2 \\
\hline
\end{tabular}

Table 2

Details of reading comprehension test

\begin{tabular}{lll}
\hline No & Reading skills & No. of questions \\
\hline 1 & Inference & 10 \\
2 & Main idea & 4 \\
3 & Reference & 5 \\
\hline
\end{tabular}

\begin{tabular}{lll}
\hline No & Reading skills & No. of questions \\
\hline 4 & Stated detail & 13 \\
5 & Unstated detail & 5 \\
6 & Vocabulary & 13 \\
\hline
\end{tabular}

PBT TOEFL was used as the instrument in this research because it has been claimed to have high validity, i.e. it is a good test which can measure EFL proficiency level (Freedle \& Kostin, 1993, p. 167; Chapelle, 2008). In addition, the level of validity to PBT TOEFL as reported by ETS (2016) is very high, i.e. 0.96. This level is in line with the level recommended by Frisbie (1988, p. 29) for a high-stakes standardized test.

\section{Procedure of Data Collection}

The test was administered at the five universities in different districts on different occasions, but all within the span of two months. To collect the data, the authors visited each of those university in cooperation with the universities. Each participant completed the test in a time span no longer than two hours, as suggested by the ETS. The time given was 30 minutes for listening section, 25 minutes for structure and written expression, and 55 minutes for reading comprehension. For listening section, the audio was delivered by using a high-quality audio player in conducive classrooms, and the participants confirmed that the volume and sound quality was satisfactory before the test. The participants who completed the test early were not allowed to leave the room in order not to distract other participants.

\section{Procedure of Data Analysis}

Before deciding a proper statistical formula to find out whether the scores obtained by social science students and natural science counterparts were significantly different, the 
data were tested for normality and homogeneity, for which a Shapiro-Wilk test and Levene's Test were used. The calculations were performed by using the statistical software SPSS. Because the data were proven to be not normally distributed, a nonparametric Mann-Whitney U Test was used to test the hypothesis. The hypothesis was that the scores obtained by students from the social and natural sciences would be similar. The hypothesis is rejected if the p-value is less than 0.05 . The results of those calculations are presented in the following section.

\section{FINDINGS}

Since the data were analysed quantitatively, the choice of formula needed to meet the criteria of the data. Therefore, before further analysis, the homogeneity and normality of the data were tested. The results are presented in Table 3.

Table 3

Normality and homogeneity tests

\begin{tabular}{llccc}
\hline \multirow{2}{*}{ No } & Data & \multicolumn{2}{c}{ Shapiro-Wilk } & \multirow{2}{*}{ Levene's Test } \\
\cline { 2 - 4 } & & Social Science & Natural Science & \\
\hline 1 & Listening & 0.000 & 0.000 & 0.588 \\
2 & Structure & 0.008 & 0.016 & 0.827 \\
3 & Reading & 0.001 & 0.058 & 0.935 \\
4 & TOEFL & 0.000 & 0.013 & 0.945 \\
\hline
\end{tabular}

The normality of the data, according to a Shapiro-Wilk test, shows that the p-values for almost all tests are less than $0.05(\mathrm{p}<0.05)$, except for the reading scores for students of natural sciences. This shows that the data are not normally distributed. Although all parts of the data are homogenous, according to Levene's Test $(p>0.05)$, the nonparametric Mann-Whitney test was used to find out whether the difference between each test score from social science students and those from natural science students is significant.

The objective of this research was to determine the performance of students from social and natural sciences in each aspect of listening, structure, and reading. Table 4 shows that, in general, students from social sciences outperformed those from natural sciences, except in the structure section. However, the difference is not statistically significant ( $\mathrm{p}$ $>0.05)$.

Table 4

Different scores obtained by students from different disciplines

\begin{tabular}{llcccc}
\hline \multirow{2}{*}{ No } & \multirow{2}{*}{ Disciplines } & \multicolumn{4}{c}{ Average Scores } \\
\cline { 3 - 5 } & & Listening & Structure & Reading & TOEFL Scores \\
\hline 1 & Social Science & 15.233 & 13.809 & 18.146 & 382.434 \\
2 & Natural Science & 15.733 & 13.956 & 18.067 & 381.963 \\
\hline & Mann-Whitney (p) & .829 & .952 & .938 & .956 \\
\hline
\end{tabular}

\section{Differences in the listening comprehension subtest}

The first part of the test is the listening test. The listening test is divided into three parts. The comparison of the scores of each part between students of social sciences and those of natural sciences is provided in Table 5. 
Table 5

Listening scores between students of social and natural sciences

\begin{tabular}{llllc}
\hline No & Test parts & Social Science & Natural Science & p-value \\
\hline 1 & Short Conversation (Part 1) & $30.26 \%$ & $30.00 \%$ & .086 \\
2 & Long Conversation (Part 2) & $35.47 \%$ & $35.56 \%$ & .810 \\
3 & Long Talk (Part 3) & $28.26 \%$ & $32.65 \%$ & .032 \\
\hline
\end{tabular}

The results of a Mann-Whitney Test for each part of the listening test show that only Part 3 (Long Talk) has a p-value $<0.05$ (0.032), which suggests that the scores obtained by students of social and natural sciences are similar for Part 1 and Part 2, but significantly different for Part 3. Figure 1 illustrates this comparison more visually.

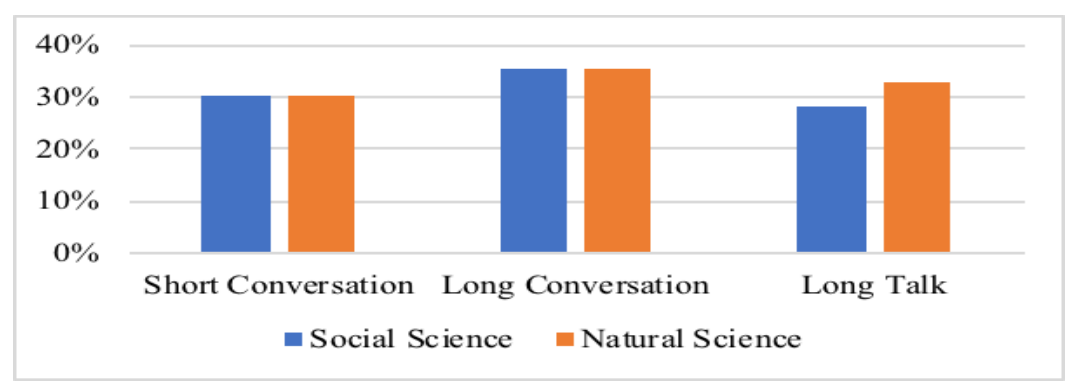

Figure 1

Listening scores between students of social and natural sciences

\section{Differences in the structure and written expression subtest}

Structure is the second section in the test. There are 14 topics tested in this subtest. Table 6 presents the scores for each topic obtained by students of social and natural sciences, along with the results of the non-parametric significance test.

Table 6

Structure scores between students of social and natural sciences

\begin{tabular}{|c|c|c|c|c|c|}
\hline \multirow[t]{2}{*}{ No } & \multirow[t]{2}{*}{ Topics } & \multirow[t]{2}{*}{ No of Item } & \multicolumn{2}{|c|}{$\begin{array}{l}\text { Percentages of correct } \\
\text { answers }\end{array}$} & \multirow[t]{2}{*}{ p-values } \\
\hline & & & SS & $\mathrm{NS}$ & \\
\hline 1 & Adjective Clause & 4 & $27.11 \%$ & $38.48 \%$ & .658 \\
\hline 2 & Adverb Clause & 2 & $37.94 \%$ & $26.97 \%$ & .373 \\
\hline 3 & Article & 2 & $44.17 \%$ & $36.29 \%$ & .158 \\
\hline 4 & Comparison & 2 & $35.90 \%$ & $28.83 \%$ & .596 \\
\hline 5 & Conjunction & 2 & $52.03 \%$ & $53.56 \%$ & .975 \\
\hline 6 & Inversion & 2 & $24.24 \%$ & $19.90 \%$ & .953 \\
\hline 7 & Noun & 3 & $26.53 \%$ & $25.35 \%$ & .874 \\
\hline 8 & Pronoun & 2 & $46.18 \%$ & $32.66 \%$ & .210 \\
\hline 9 & Reduced Adj. Clause & 2 & $23.48 \%$ & $29.48 \%$ & .240 \\
\hline 10 & Reduced Adv. Clause & 2 & $26.09 \%$ & $13.04 \%$ & .660 \\
\hline 11 & Subject and Verb & 4 & $42.19 \%$ & $65.16 \%$ & .965 \\
\hline 12 & Verb form & 6 & $33.37 \%$ & $35.26 \%$ & .746 \\
\hline 13 & Word Form & 6 & $27.86 \%$ & $27.35 \%$ & .499 \\
\hline 14 & Word Order & 2 & $26.60 \%$ & $23.01 \%$ & .661 \\
\hline
\end{tabular}


Based on the average percentages of correct answers, it is evident that there are some topics in which a difference can be visually spotted. However, none of the percentages are significantly different, because the p-values for all topics are higher than 0.05.

\section{Differences in the reading comprehension subtest}

The last section in the assessment instrument is the reading test, which examines six reading skills, i.e. vocabulary, stated detail, unstated detail, inference, main idea, and reference. The comparison of the average percentages of correct answers for each skill is presented in Table 7 .

Table 7

Reading scores between students of social and natural sciences

\begin{tabular}{llcccc}
\hline No & Reading skills & $\begin{array}{c}\text { No of } \\
\text { Item }\end{array}$ & \multicolumn{2}{c}{$\begin{array}{c}\text { Percentages of correct } \\
\text { answers }\end{array}$} & p-values \\
\cline { 3 - 5 } & & SS & NS & \\
\hline 1 & Vocabulary & 13 & $32.83 \%$ & $34.56 \%$ & .636 \\
2 & Stated detail & 13 & $34.04 \%$ & $38.29 \%$ & .232 \\
3 & Inference & 10 & $28.00 \%$ & $28.87 \%$ & .823 \\
4 & Unstated detail & 5 & $34.82 \%$ & $35.75 \%$ & .527 \\
5 & Main idea & 4 & $41.18 \%$ & $33.07 \%$ & .021 \\
6 & Reference & 5 & $50.59 \%$ & $51.51 \%$ & .351 \\
\hline
\end{tabular}

Based on the statistical analysis presented in Table 6, evidence of significant differences in the average percentage of correct answers between students of social and natural sciences is only found in the "main idea" aspect $(\mathrm{p}<0.05)$. Although there are differences in other skills, none are statistically significant. A better illustration of these differences is presented in Figure 2.

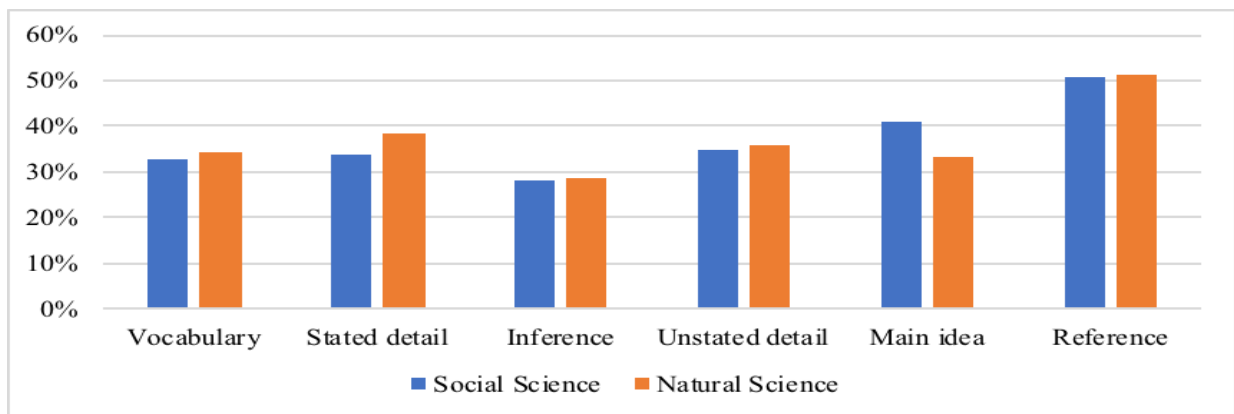

Figure 2

Reading scores between students of social and natural sciences

\section{DISCUSSION}

The objective of this research was to determine differences in achievement between students from social and natural sciences in the aspects of listening, structure, and reading. The data were collected by administering a Test of English as a Foreign Language (TOEFL) to 179 students from the two disciplines. The general results show that their achievement in the tests is similar. The differences were only found in one aspect of the listening section and in one skill tested in the reading section. 
These results were initially unexpected because previous studies predicted that students from social sciences learn English differently than students from natural sciences. Therefore, students from the different disciplines were expected to obtain different learning outcomes. However, the current study did not show evidence for the predicted difference. It is hypothesized that this unexpected result occurred for several reasons. First, the participants examined in this research mostly had low English proficiency, i.e. an average score of 383 on a paper-based TOEFL, or the level of A2 in CEFR (Tannenbaum \& Baron, 2012, p. 12). Since there is a consensus that low English proficiency students use a limited number of learning strategies (Hashemi \& Hadavi, 2015, p. 634; O’Malley \& Chamot, 1990, p. 127; Salahshour et al., 2013, p. 640), it can be assumed that the participants in the current study, both from social and natural sciences, use somewhat similar learning strategies. Therefore, the difference in learning outcomes was expected to be small. In addition, although the majority of participants in the current study were basic English learners, some of them (13 participants from the social sciences and 19 from the natural sciences) were intermediate English learners. Separating the participants based on their English proficiency would not have been useful because it is not feasible in a real teaching environment, at least in the case of students in Indonesia. Consequently, both groups consisted of participants with mixed levels of English proficiency. Second, English is taught in Indonesia starting at a threeyear junior high school level. Students are divided into social science and natural science majors when they are in the third year of junior high school. Thus, they have been learning English together for seven years before being separated. During the learning process, students might have shared their opinions on the best learning strategies, as in Vandergrift (2003, p. 429), or they may have adopted the strategies employed by successful learners because, unlike learning style, which is innate, learning strategies are learnable. This possibility leads to the potential conclusion that students from both social and natural sciences use the same language learning strategies.

Significant differences in scores obtained in the proficiency test between students from the social and natural sciences were only found in the sections consisting of listening to a short talk and finding the main idea in a reading. These skills are correlated with vocabulary (Hiebert \& Kamil, 2005, p. 6; Vandergrift \& Goh, 2012, p. 24). Students from different disciplines have been exposed to English texts that are different depending on the discipline. Vocabulary is incidentally acquired during this exposure (Eckerth \& Tavakoli, 2012, pp. 241-242). In Part 3 of the listening comprehension subtest, the subjects use academic language; therefore, academic vocabulary is required to comprehend the talk. Because students from social and natural sciences are exposed to different academic vocabulary, their level of understanding of the talk is expectedly different. The current study has revealed that students exposed to academic vocabulary in the natural sciences are likely to understand academic talks better than those exposed to academic vocabulary in the social sciences.

The other significant difference was found in the ability to grasp the main idea of a text. The current study shows that students from the social sciences were more proficient in gaining a general understanding of an academic text than those from the natural sciences. Like listening, vocabulary also plays a pivotal role in reading comprehension. 
General vocabulary is more correlated to understanding the main idea in reading than discipline-specific vocabulary. Mozaffari and Moini (2014, p. 1292) and Valipouri and Nassaji (2013, p. 253) found that students from social sciences are exposed to more non-academic vocabulary than academic vocabulary, to which natural science students are more exposed. The results of the current research suggest that students who are exposed to more general vocabulary gain a better general comprehension of a nonsubject specific academic text than students exposed more to academic vocabulary. This unexpected conclusion is supported by the fact that, based on the authors' vocabulary analysis, non-subject specific academic texts, as in TOEFL, contain more general vocabulary than academic vocabulary. Only 5\% of the vocabulary found in these texts is listed in the New Academic Word List provided by Cobb (2018).

\section{Limitations of the study}

This research has revealed the details of differences between the scores of students in the social and natural sciences on an English proficiency test. However, most participants in this research obtained TOEFL scores that were lower than 400. Mustafa and Anwar (2018) found that TOEFL scores which are lower than 400 cannot be confidently used to judge students' proficiency. Therefore, the results of this research are only applicable for low-proficiency learners. High-proficiency learners might demonstrate different tendencies.

\section{CONCLUSION}

This research was aimed at finding differences in scores in the components of listening, structure, and reading between students of social and natural sciences. Based on a statistical analysis, only one component in the listening section and another in the reading section showed significant differences. The data suggest that natural science students are able to understand long talks better than social science students when listening to native speakers of English in an academic setting, whereas, social science students are able to understand the main idea of a written academic text more easily than their natural science counterparts. Based on these results, teachers should teach students from both disciplines similarly because they tend to show similar results in performance on most parts of the English proficiency test. However, further research involving only intermediate and advanced level students will help teachers better decide the foci of their teaching.

\section{ACKNOWLEDGEMENTS}

The authors express their gratitude to Syiah Kuala University, which financially supported this research under a professor research scheme.

\section{REFERENCES}

Abdul, Z., \& Abboud, R. (2011). The Difficulties Faced By Advanced Iraqi foreign Learners in Passing ITP TOEFL Test. Journal of Basrah Researches, 36(4), 110-138.

Alavi, S. M., \& Akbarian, I. (2012). The Role of Vocabulary Size in Predicting Performance on TOEFL Reading Item Types. System, 40(3), 376-385.

Ananda, R. (2016). Problems with Section Two ITP TOEFL Test. Studies in English Language and Education, 3(1), 37-51. 
Brown, D. (2004). Language Assessment: Principles and Classroom Practices. New York: Longman.

Chapelle, C. A. (2008). The TOEFL Validity Argument. In C. A. Chapelle, M. K. Enright, \& J. M. Jamieson (Eds.), Building a Validity Argument for the Test of English as a Foreign Language ${ }^{T M}$ (p. 725). New York: Routledge Taylor \& Francis Group.

Cobb, T. (n.d.). Compleat Web VP! Retrieved January 21, 2018 from https://lextutor.ca/vp/comp/neo_classic_heads/ngsl_heads(4).txt

Darasawang, P. (2007). English Language Teaching and Education in Thailand: A Decade of Change. In D. Prescott (Ed.), English in Southeast Asia: Varieties, Literacies and Literatures (pp. 187-204). Newcastle: Cambridge Scholars Publishing.

Dewaele, J.-M. (2013). Learner-internal Psychological Factors. In J. Herschensohn \& M. Young-Scholten (Eds.), The Cambridge Handbook of Second Language Acquisition (pp. 159-179). Cambridge: Cambridge University Press.

Doryei, Z. (2007). Research Methods in Applied Linguistics: Quantitative, Qualitative, and Mixed Methodologies. Oxford: Oxford University Press.

Durrant, P. (2016). To What Extent Is The Academic Vocabulary List Relevant To University Student Writing? English for Specific Purposes, 43, 49-61.

Eckerth, J., \& Tavakoli, P. (2012). The Effects of Word Exposure Frequency and Elaboration of Word Processing on Incidental L2 Vocabulary Acquisition Through Reading. Language Teaching Research, 16(2), 227-252.

Ehrman, M. E., Leaver, B. Lou, \& Oxford, R. L. (2003). A Brief Overview of Individual Differences in Second Language Learning. System, 31(3), 313-330.

Ensslin, A., \& Krummes, C. (2013). Electronic Interaction and Resources. In J. Herschensohn \& M. Young-Scholten (Eds.), The Cambridge Handbook of Second Language Acquisition (pp. 292-312). Cambridge: Cambridge University Press.

ETS. (2016). TOEFL ITP® reliability table. Retrieved August 15, 2016, from https://www.ets.org/s/toefl_itp/pdf/toefl_itp_score.pdf

Foley, C., \& Flynn, S. (2013). The Role of The Native Language. In J. Herschensohn \& M. Young-Schholten (Eds.), The Cambridge Handbook of Second Language Acquisition (pp. 97-113). Cambridge: Cambridge University Press.

Freedle, R., \& Kostin, I. (1993). The Prediction of TOEFL Reading Item Difficulty: Implications For Construct Validity. Language Testing, 10(2), 133-170.

Frisbie, D. A. (1988). Reliability of Scores From Teacher-Made Tests. Educational Measurement: Issues and Practice, 7(1), 25-35.

Gaudart, H. (1987). English Language Teaching in Malaysia: A Historical Account. The English Teacher, 16, 17-36.

Griffiths, C., \& Oxford, R. L. (2014). The Twenty-First Century Landscape of Language Learning Strategies: Introduction To This Special Issue. System, 43(1), 1-10.

Harish, S. (2014). Social Strategy Use and Language Learning Contexts: A Case Study 
of Malayalee Undergraduate Students in India. System, 43(1), 64-73.

Hashemi, Z., \& Hadavi, M. (2015). Investigation of Vocabulary Learning Strategies Among EFL Iranian Medical Sciences Students. Procedia - Social and Behavioral Sciences, 192, 629-637.

Herschensohn, J., \& Young-Schholten, M. (2013). The Cambridge Handbook od Second Language Acquisition. Cambridge: Cambridge University Press.

Hiebert, E. H., \& Kamil, M. L. (2005). Teaching and Learning Vocabulary: Bringing Research to Practice. New Jersey: Lawrence Erlbaum Associates.

Hilgendorf, S. K. (2012). History of Language Teaching Methods. In The Encyclopedia of Applied Linguistics (pp. 2522-2525). New Jersey: Blackwell Publishing Ltd.

Hong-Nam, K., \& Leavell, A. G. (2006). Language Learning Strategy Use of ESL Students in An Intensive English Learning Context. System, 34(3), 399-415.

Howatt, A. P. R. (1984). A History of English Language Teaching. Oxford: Oxford University Press.

Howatt, A. P. R., \& Smith, R. (2014). The History of Teaching English as a Foreign Language, from a British and European Perspective. Language \& History, 57(1), 75-95.

Khurshid, F., \& Mahmood, N. (2012). Learning Styles of Natural Sciences, Social Sciences and Humanities Students at Graduate Level. Interdisciplinary Journal of Contemporary Research in Business, 3(9), 672-678.

Kothari, C. R. (2004). Research Methodology: Methods and Techniques. New Delhi: New Age International (P) Limited.

Litzinger, T. A., Lee, S. H., Wise, J. C., \& Felder, R. M. (2005). A Study of The Reliability and Validity of The Index of Learning Styles. In Proceedings of the 2005 American Society for Engineering Education Annual Conference \& Exposition.

Løfsgaard, K. A. (2015). The History of English Education in Japan - Motivations, Attitudes and Methods (Master's thesis). Retrieved from https://www.duo.uio.no/ handle/10852/45769

Luo, J., \& Weil, N. (2014). Language Learning Strategy Use In An American IEP: Implications for EFL. Asian EFL Journal, 16(3), 96-115.

Mayo, M. del P. G., \& Soler, E. A. (2013). Negotiated Input and Output / Interaction. In J. Herschensohn \& M. Young-Scholten (Eds.), The Cambridge Handbook of Second Language Acquisition (pp. 209-229). Cambridge: Cambridge University Press.

Miller, E. R., \& Kubota, R. (2013). Second Language Identity Construction. In J. Herschensohn \& M. Young-Scholten (Eds.), The Cambridge Handbook of Second Language Acquisition (pp. 230-250). Cambridge: Cambridge University Press.

Mozaffari, A., \& Moini, R. (2014). Academic Words in Education Research Articles: A Corpus Study. Procedia - Social and Behavioral Sciences, 98, 1290-1296.

Muslem, A., \& Abbas, M. (2017). The Effectiveness of Immersive Multimedia Learning with Peer Support on English Speaking and Reading Aloud. International Journal of 
Instruction, 10(1), 203-218.

Mustafa, F. (2015). Using Corpora to Design A Reliable Test Instrument for English Proficiency Assessment. In TEFLIN International Conference (pp. 344-352). Denpasar.

Mustafa, F., \& Anwar, S. (2018). Distinguishing TOEFL Score: What is The Lowest Score Considered a TOEFL Score?. Pertanika Journal of Social Science and Humanities, 26(3), 1995-2008.

Mustafa, F., \& Apriadi, H. (2016). DIY: Designing A Reading Test As Reliable As A Paper-Based TOEFL Designed by ETS. In Current Trends in Languages and Education (pp. 402-407). Banda Aceh.

Nation, P., \& Waring, R. (1997). Vocabulary Size, Text Coverage and Word Lists. In N. Schmitt \& M. McCarthy (Eds.), Vocabulary: Description, Acquisition and Pedagogy (pp. 6-20). Cambridge: Cambridge University Press.

O’Malley, J. M., \& Chamot, A. U. (1990). Learning Strategies in Second Language Acquisition. Cambridge: Cambridge University Press.

Peacock, M., \& Ho, B. (2003). Student language learning strategies across eight disciplines. International Journal of Applied Linguistics, 13(2), 179-200.

Phillips, D. (2003). Longman Preparation Course for the TOEFL. New York: Pearson Education.

Putra, T. M., Kasim, U., \& Mustafa, F. (2017). Reading Comprehension in PBT TOEFL: What Sub-Skills Deserve More Intensive Training? In International Conference on the Teaching and Learning of Languages. Serawak, Malaysia.

Putri, A. A., Lubis, L., \& Sutaryan, T. M. (2014). Differences of Anxiety Levels Between Students of Natural Sciences and Social Studies Major Based on School Environmental Factors in Senior High Schools with Rintisan Sekolah Bertaraf Internasional Scheme. Althea Medical Journal, 1(2), 65-69.

Regan, V. (2013). Variation. In J. Herschensohn \& M. Young-Schholten (Eds.), The Cambridge Handbook of Second Language Acquisition (pp. 272-291). Cambridge: Cambridge University Press.

Sahragard, R., Khajavi, Y., \& Abbasian, R. (2016). Field of Study, Learning Styles, and Language Learning Strategies of University Students: Are There Any Relations? Innovation in Language Learning and Teaching, 10(3), 255-271.

Salahshour, F., Sharifi, M., \& Salahshour, N. (2013). The Relationship Between Language Learning Strategy Use, Language Proficiency Level and Learner Gender. Procedia - Social and Behavioral Sciences, 70(1957), 634-643.

Sánchez, A. (2014). Spanish As A Foreign Language in Europe: Six Centuries of Teaching Materials. Language \& History, 57(1), 59-74.

Schmitt, N. (2000). Vocabulary in language teaching. Cambridge: Cambridge 
University Press.

Schwartz, B. D., \& Sprouse, R. A. (2013). Generative Approaches and The Poverty of the Stimulus. In J. Herschensohn \& M. Young-Scholten (Eds.), The Cambridge Handbook of Second Language Acquisition (pp. 137-158). Cambridge: Cambridge University Press.

Shaukat, S., \& Bashir, M. (2015). University Students' Academic Confidence: Comparison Between Social Sciences and Natural Science Disciplines. Journal of Elementary Education, 25(2), 113-123.

Simpson-Vlach, R. (2012). Corpus Analysis of Spoken English for Academic Purposes. In The Encyclopedia of Applied Linguistics. Oxford: Blackwell Publishing Ltd.

Tannenbaum, R. J., \& Baron, P. A. (2012). Mapping the TOEFL ITP Tests ontoThe Common European Framework of Reference. New Jersey.

Tarone, E., Hansen, K., \& Bigelow, M. (2013). Alphabetic Literacy and Adult SLA. In J. Herschensohn \& M. Young-Scholten (Eds.), The Cambridge Handbook of Second Language Acquisition (pp. 180-204). Cambridge: Cambridge University Press.

Towell, R. (2013). Learning Mechanisms and Automanization. In J. Herschensohn \& M. Young-Schholten (Eds.), The Cambridge Handbook of Second Language Acquisition (pp. 115-136). Cambridge: Cambridge University Press.

Tsuchiya, K. (1975). The Taman Siswa Movement: Its Early Eight Years and Javanese Background. Journal of Southeast Asian Studies, 6(1), 61-86.

Valipouri, L., \& Nassaji, H. (2013). A Corpus-Based Study of Academic Vocabulary in Chemistry Research Articles. Journal of English for Academic Purposes, 12(4), 248263.

Vandergrift, L. (2003). From Prediction Through Reflection: Guiding Students Through The Process of L2 Listening. Canadian Modern Language Review, 59(3), 425-440.

Vandergrift, L., \& Goh, C. C. M. (2012). Teaching and Learning Second Language Listening: Metacognition In Action. New York: Routledge.

Véronique, G. D. (2013). Socialization. In J. Herschensohn \& M. Young-Scholten (Eds.), The Cambridge Handbook of Second Language Acquisition (pp. 251-271). Cambridge: Cambridge University Press.

Wang, L. (2007). Variation in Learning Styles In A Group of Chinese English As A Foreign Language Learners. International Education, 8(2), 408-417.

Zafar, S., \& Meenakshi, K. (2012). Individual Learner Differences and Second Language Acquisition: A Review. Journal of Language Teaching and Research, 3(4), 639-646. 